\title{
Peningkatan Hasil Belajar Matematika Melalui Strategi Pembelajaran Mantel Sang Ahli
}

\author{
Nurfadilah Mahmud \\ Program Studi Pendidikan Matematika FMIPA Universitas Sulawesi Barat \\ e-mail: 1nurfadilahmahmud@yahoo.com
}

\begin{abstract}
Abstrak
Penelitian ini bertujuan untuk mengetahui peningkatan hasil belajar matematika dengan menerapkan Strategi Mantel Sang Ahli pada siswa kelas VIIIA SMP Negeri 1 Tinambung Polewali Mandar. Strategi Mantel Sang Ahli adalah suatu strategi yang memanfaatkan kondisi anak yang suka pamer dengan orientasi pembelajaran berpusat pada siswa (student-centred) sehingga dapat mengembangkan motivasi siswa, kreatifitas dan keterampilan mengemukakan ide atau gagasan di depan publik yang akan meningkatkan hasil belajar siswa. Penelitian ini terdiri dari dua siklus. Pengambilan data dilakukan beberapa tahap yaitu : test awal, siklus I dan siklus II. Data yang terkumpul dianalisis dengan menggunakan analisis kualitatif dan kuantitatif. Hasil analisis data memperlihatkan bahwa: (1) pada test awal sebelum diterapkan strategi Mantel Sang Ahli diperoleh nilai rata-rata Hasil belajar matematika siswa sebesar 30,86 dari nilai ideal 100. (2) pada siklus I, diperoleh nilai rata-rata hasil belajar matematika siswa sebesar 60,58 dari nilai ideal 100, sedangkan presentase dari nilai ketuntasan minimal sebesar 41,67\% sehingga masih dilanjutkan ke siklus II. (3) pada siklus II, diperoleh nilai rata-rata hasil belajar matematika siswa sebesar 76,16 dari nilai ideal 100, presentase siswa yang mencapai kriteria ketuntasan minimal sebesar $87,50 \%$. (4) keaktifan siswa terhadap strategi pembelajaran yang digunakan meningkat dilihat dari peningkatan respon positif siswa terhadap situasi yang diberikan dari siklus I ke siklus II. Jadi penerapan Strategi Mantel Sang Ahli dapat meningkatkan hasil belajar matematika siswa kelas VIIIA SMP Negeri 1 Tinambung Kabupaten Polewali Mandar.
\end{abstract}

Kata kunci-Hasil Belajar Matematika, Strategi Pembelajaran, Mantel Sang Ahli

\section{PENDAHULUAN}

Pendidikan telah menjadi kebutuhan dalam kehidupan bermasyarakat dan bernegara.Pendidikan merupakan pilar bagi tiap bangsa dan sebagai tolak ukur bagi peningkatan kualitas suatu bangsa secara totalitas. Upaya peningkatan mutu pendidikan adalah bagian yang harus menjadi prioritas bagi perbaikan kualitas sumber daya manusia (SDM). Hal ini berarti pendidikan menekankan mutu sumber daya manusia yang kompeten, kreatif, terampil, dan bertanggung jawab terhadap bangsa dan bernegara.

Jadi pendidikan dapat dimaknai sebagai proses mengubah tingkah laku anak didik agar menjadi manusia dewasa yang mampu hidup mandiri dan menjadi anggota masyarakat yang berilmu dan memiliki skill, etika yang baik dimana individu itu berada. Pendidikan tidak hanya mencakup pengembangan intelektual saja, akan tetapi lebih ditekankan pada proses pembinaan kepribadian anak didik secara menyeluruh sehingga anak menjadi lebih dewasa (Sagal, 2010).

Matematika perlu diajarkan kepada semua jenjang pendidikan karena dengan belajar matematika secara tidak langsung dapat membekali peserta didik berupa kemampuan berfikir logis, analitis, sistematis, kritis, dan kreatif, serta kemampuan bekerjasama. Kompetisi tersebut diperlukan agar peserta didik dapat memiliki kemampuan dalam memanfaatkan informasi dan tetap istiqomah (konsisten), tidak mudah terbawa arus pada keadaan yang selalu berubah, tidak pasti, dan kompetitif. 
JURNAL SAINTIFIK VOL.2 NO.1, JANUARI 2016

SMP Negeri 1 Tinambung adalah sekolah yang terletak di Provinsi Sulawesi Barat, tepatnya di Kabupaten Polewali Mandar. Berdasarkan fakta berupa data yang penulis dapatkan melalui hasil wawancara langsung dengan guru kelas bidang studi matematika siswa kelas VIIIA SMP Negeri 1 Tinambung bahwa selama ini strategi pembelajaran yang diterapkan masih model konvensional yaitu pengajaran langsung yang pada dasarnya mengunakan metode ceramah atau hanya menulis materi pelajaran di papan tulis. Tidak setiap siswa memiliki karakteristik yang sama. Beberapa masalah pun ditemukan dalam proses belajar mengajar di kelas seperti siswa yang kurang aktif, hanya sekitar $20 \%$ dari 24 siswa yang bisa dikatakan aktif di kelas sedangkan siswa yang lain hanya ingin ke papan tulis untuk mengerjakan contoh soal dan latihan jika di tunjuk oleh gurunya. Siswa juga masih sulit mengutarakan ide atau gagasan dan segan untuk bertanya kepada guru tentang materi yang belum mereka pahami. Situasi ini terjadi karena tidak adanya rasa percaya diri pada siswa tersebut. Kemudian hasil belajar berupa nilai ulangan harian yang siswa peroleh adalah $75 \%$ siswa tidak mencapai nilai optimal. Masalah-masalah seperti inilah yang perlu dirubah dan diperbaiki.

Belajar mengajar merupakan kegiatan aktif siswa dalam menanamkan pengertian atau pemahaman. Ketika hasil belajar yang diperoleh siswa SMP Negeri 1 Tinambung kurang maksimal atau tidak mencapai titik tujuan yang optimal, berarti siswa kurang paham atas materi yang telah diberikan, hal ini disebabkan motivasi siswa yang kurang, karena tidak adanya variasi dalam proses pembelajaran sehingga siswa cepat bosan apalagi matematika menurut anak-anak adalah pelajaran yang cukup sulit. Siswa juga segan kepada gurunya untuk bertanya. Agar peserta didik belajar secara aktif dan memperoleh hasil belajar yang maksimal, guru perlu menciptakan strategi yang tepat guna, sehingga peserta didik mempunyai motivasi yang tinggi untuk belajar.

Mantel Sang Ahli adalah salah satu strategi yang sesuai untuk mengatasi masalah yang dihadapi oleh siswa kelas VIIIA SMP Negeri 1 Tinambung tersebut. Dengan menerapkan Mantel Sang Ahli dalam pembelajaran di kelas, tentunya akan melatih rasa percaya diri siswa, karena strategi ini memberikan sugesti dan motivasi kepada siswa untuk berani tampil dan membuktikan bahwa dia pun tidak kalah pintar dengan siswa yang lain. Dikatakan memberikan sugesti karena penerapan strategi ini siswa mengenakan mantel atau jubah layaknya anak remaja atau penyihir terkenal seperti yang siswa biasa saksikan di TV dengan penampilan yang rapi dan trendi. Melihat pakaian yang dikenakan oleh siswa adalah sebuah Mantel, siswa sudah tertarik dan akhirnya termotivasi untuk bisa tampil di hadapan teman-temannya. Jadi sebelum siswa belajar matematika, mereka sudah mencari-cari informasi yang berkaitan dengan materi yang akan diajarkan di sekolah nantinya. Selain itu, karena strategi ini sistemnya adalah siswa secara individu yang akan menjelaskan mengenai materi yang dipelajari, maka siswa yang lain tidak perlu malu untuk bertanya karena yang melakukan presentasi di depan kelas adalah teman siswa itu sendiri. Ketika minat dan motivasi telah dimiliki oleh siswa maka mereka akan selalu berusaha untuk mencari ilmu, belajar dengan rajin di rumah dan dampak positif pada hasil belajar siswa pun akan meningkat seperti yang diharapkan.

Strategi Mantel sang ahli juga sejalan dengan perubahan orientasi pembelajaran saat ini yang semula berpusat pada guru (teacher centered) beralih berpusat pada murid (student centered). Perubahan orientasi pembelajaran dimaksudkan untuk memperbaiki mutu pendidikan, baik dari segi proses maupun hasil pendidikan dalam Trianto (2008).

Menurut para pakar pendidikan Mantel Sang Ahli dalam Brian (2010) adalah lebih dari kumpulan ide atau kegiatan. Ini adalah sebuah sistem pedagogis yang bisa merevolusi pendidikan. Mungkin paling inovatif karena terdapat tujuan untuk terus meningkatkan kesadaran siswa bagaimana bertanggung jawab yang ditimbulkan dari keahlian tertentu dan aktivitas yang ia lakukan tentunya sangat bemakna. Bahkan dalam Primer Strategi Nasional telah menaruh kepercayaan pada guru untuk menerapkan metode ini dalam pembelajaran.

Untuk lebih jelasnya, langkah-langkah dari strategi ini dalam Ginnis (2008) adalah sebagai berikut: 
1. Menjelaskan bahwa sebuah topik baru akan dimulai. Kemudian menyampaikan tujuan pembelajaran, sampaikan ringkasan dari isi.

2. Minta orang mencatat apa yang telah mereka ketahui, atau dapat dilakukan, berkaitan dengan aspek apa pun dari topik ini. Anda mungkin minta mereka bertukar detail ini berpasangan.

3. Minta seseorang sukarelawan untuk maju, memakai mantel sang ahli dan bercerita ke kelas apa yang ia ketahui atau dapat lakukan.

4. Kelas dapat bertanya, sang ahli memiliki hak untuk berkata "lewat" bila dia tidak yakin akan jawabannya dan guru dapat menambahkan komentar.

5. Sukarelawan lain dicari "Siapa dapat menambahkan apa yang dikatakan temannya ?" dan proses berlanjut.

Cara kerja Mantel sang ahli dalam pembelajaran adalah siswa harus berlakon sebagai guru dengan menggunakan Mantel di depan teman-temannya untuk menjelaskan materi yang ia ketahui berdasarkan tema yang telah disampaikan oleh guru. Metode ini akan melatih imajinasi siswa, keterampilan berbicara, termotivasi untuk belajar dan secara tidak langsung siswa menyadari bagaimana kegiatan seorang guru yang sebenarnya. Sungguh merupakan suatu tantangan bagi siswa dan dengan sendirinya siswa akan lebih menghargai profesi seorang guru. Penggunaan Mantel Sang Ahli ini cocok untuk semua jenis mata pelajaran termasuk dalam bidang matematika.

Berdasarkan uraian dari latar belakang di atas, maka permasalahan yang akan dikaji dalam penelitian ini adalah" Apakah dengan Strategi Pembelajaran Mantel Sang Ahli dapat meningkatkan hasil belajar matematika pada siswa kelas VIIIA SMP Negeri 1 Tinambung Polewali Mandar ?".

\section{METODE PENELITIAN}

\subsection{Jenis Penelitian}

Penelitian ini merupakan penelitian Tindakan Kelas (classroom Action Research). Pelaksanaan penelitian bersifat kolaboratif. Model penelitian tindakan kelas yang digunakan adalah model yang ditawarkan oleh Kemmis dan McTaggart (Kunandar, 2010) yang terdiri dari empat "momentum essensial" yaitu yaitu, perencanaan (Planning), pelaksanaan (Action), observasi (Observation), dan refleksi (Reflection).

Adapun desain penelitian tindakan kelas yang digunakan adalah dalam Arikunto (2009) sebagai berikut:

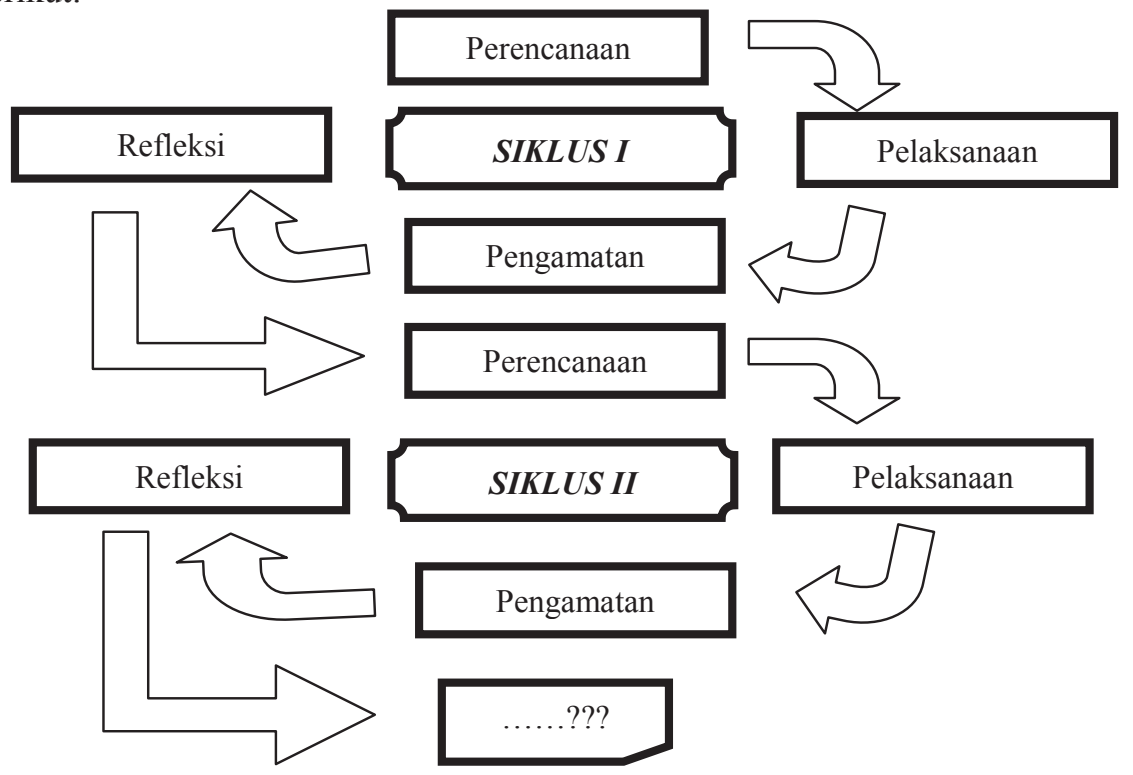

Gambar 1. Siklus dalam Penelitian Tindakan Kelas 
JURNAL SAINTIFIK VOL.2 NO.1, JANUARI 2016

\subsection{Subjek Penelitian}

Penelitian ini dilaksanakan di SMP Negeri 1 Tinambung Kab.Polewali Mandar dengan subjek penelitian adalah siswa kelas VIIIA semester II sejumlah 24 orang.

\subsection{Prosedur Penelitian}

Penelitian ini terdiri dari dua siklus artinya bisa lebih dari 2 siklus, sampai terjadi perubahan berdasarkan tujuan penelitian yang telah ditetapkan. Siklus II dilakukan apabila peneliti ingin mendapatkan data yang lebih akurat dan apabila hasil belajar dari siklus I yang diketahui melalui hasil refleksi, tidak berhasil. Secara rinci tahap-tahap yang dilakukan dalam penelitian ini adalah sebagai berikut:

\subsubsection{Tahap Perencanaan}

\section{Gambaran Umum Siklus I}

Kegiatan yang dilakukan yang dilakukan antara lain:

- Menyusun perangkat pembelajaran seperti silabus dan sistem penilaian, rencana pelaksanaan pembelajaran (RPP), serta menyiapkan alat dan bahan yang terkait dengan pelaksanaan pembelajaran.

- Menyiapkan alat evaluasi berupa tes tertulis yang digunakan untuk mengetahui hasil belajar kognitif siswa.

- Menyusun lembar observasi untuk penilaian afektif dan psikomotorik siswa selama proses pembelajaran berlangsung.

\subsubsection{Tahap Pelaksanaan.}

Pada tahap ini kegiatan yang dilakukan adalah aplikasi dari kegiatan yang telah direncanakan berupa penerapan skenario pembelajaran mengunakan Mantel Sang Ahli berdasarkan aturan kurikulum, rencana pelaksanaan pembelajaran yang telah dibuat (RPP), dan pemberian tes untuk meningkatkan hasil belajar Matematika.

\subsubsection{Tahap Observasi}

Tahap observasi (pengamatan) terdiri dari kegiatan yang menggambarkan uraian pengambilan data melalui lembar observasi yang telah dibuat untuk menilai semua kegiatan siswa di kelas antara lain:

a. Kehadiran siswa di kelas.

b. Disiplin waktu.

c. Keaktifan bertanya, menanggapi pertanyaan danketerampilan dalam berbicara.

d. Perhatian siswa ke materi yang disampaikan oleh temannya.

e. Keberanian tampil ke depan untuk menjelaskan ke teman-teman materi dengan mengenakan Mantel Sang Ahli.

\subsubsection{Tahap Refleksi}

Merupakan kegiatan yang berkenaan dengan proses dan dampak tindakan perbaikan yang dilakukan. Dari hasil observasi atau pengamatan, guru dan peneliti merefleksi apakah pembelajaran menggunakan strategi pembelajaran Mantel Sang Ahli dapat meningkatkan hasil belajar siswa. Kemudian hasil dari refleksi ini digunakan untuk memperbaiki perencanaan yang telah dilakukan dan digunakan untuk memperbaiki kinerja peneliti pada pembelajaran selanjutnya yaitu pada siklus II.

\section{Gambaran Umum Siklus II}

Tahapan pada siklus ini tidak jauh berbeda dengan kegiatan siklus I. Hanya saja kegiatan di siklus II ini berdasarkan hasil refleksi yang dilakukan pada siklus I. Siklus II ini sebagai bentuk penyempurnaan dari siklus I atau perbaikan segala kekurangan pada siklus I dengan strategi Mantel Sang Ahli. 


\subsection{Instrumen Penelitian}

Adapun instrumen penelitian yang digunakan adalah tes hasil belajar dalam bentuk uraian dan lembar observasi yang menjadi pedoman untuk mengukur respon siswa terhadap strategi pembelajaran Mantel Sang Ahli dengan mengamati semua aktifitas di kelas selama proses pembelajaran berlangsung.

\subsection{Teknik Pengumpulan Data} adalah:

Adapun Teknik pengumpulan data yang digunakan dalam penelitian tindakan kelas ini

2. Data tentang hasil belajar siswa diambil melalui tes ulangan yang diberikan kepada siswa di tiap siklus.

3. Data tentang pelaksanaan pembelajaran Mantel Sang Ahli diambil melalui lembar observasi.

\subsection{Teknik Analisis Data}

Penelitian ini menggunakan analisis data deskriptif dengan cara memberikan gambaran mengenai hasil belajar siswa melalui tes dan lembar observasi pada tiap siklus. Jenis data yang dikumpulkan dalam penelitian ini yaitu data kuantitatif untuk hasil belajar siswa dan data kualitatif untuk memberikan gambaran sikap siswa terhadap strategi yang diterapkan. Adapun statistik deskriptif yang dimaksud adalah sebagai berikut:

1. Menghitung nilai rata-rata hasil belajar siswa (Tiro, 2000).

$$
\bar{x}=\frac{\sum_{\mathrm{i}=1}^{\mathrm{n}} \mathrm{x}_{\mathrm{i}}}{\mathrm{n}}
$$

Keterangan:

$\bar{x}=$ Rata - rata

$x_{i}=$ jumlah keseluruhan nilai

$\mathrm{n}=$ Banyaknya data

2. Presentase (Sudijono, 2004)

$P=\frac{f}{N} \times 100 \%$

Keterangan :

$\mathrm{P}=$ Angka persentase

$f=$ Frekuensi

$N=$ Banyaknya responden

3. Membuat kategori penilaian hasil belajar kognitif siswa

Kategori hasil belajar kognitif siswa digunakan sebagai pedoman untuk mengukur hasil belajar siswa dalam bentuk standar nilai yang telah ditetapkan. Interval standar nilai berdasarkan aturan Depdikbud (1994) adalah sebagai berikut:

Tabel 1. Tingkat Penguasaan Materi

\begin{tabular}{|c|c|c|}
\hline No. & Interval Nilai & Kategori \\
\hline 1 & $0-34$ & Sangat Rendah \\
\hline 2 & $35-54$ & Rendah \\
\hline 3 & $55-64$ & Sedang \\
\hline 4 & $65-84$ & Tinggi \\
\hline 5 & $85-100$ & Sangat Tinggi \\
\hline
\end{tabular}


JURNAL SAINTIFIK VOL.2 NO.1, JANUARI 2016

4. Indikator Keberhasilan

Indikator kinerja yang menjadi tolok ukur untuk mencapai keberhasilan dalam penelitian ini adalah berdasarkan aturan dari pihak sekolah yang disesuaikan dengan ketetapan dari depdiknas yaitu seorang siswa dikatakan tuntas belajar jika memperoleh skor minimal 65 dan tuntas secara klasikal apabila minimal $85 \%$ dari jumlah siswa yang telah tuntas belajar.

\section{HASIL DAN PEMBAHASAN}

Jenis penelitian yang digunakan oleh peneliti dalam penelitian ini adalah penelitian tindakan kelas (Classroom Action Research) yang bertujuan untuk memperbaiki dan meningkatkan hasil belajar matematika siswa.Jumlah siklus dalam penelitian ini terdiri dari dua siklus.

Sebelum strategi diterapkan, terlebih dahulu dilakukan test awal siswa, hal ini dilakukan untuk mengukur sejauh mana kemampuan siswa sebelum dilakukan tindakan yaitu pelaksanaan strategi Mantel Sang Ahli. Pada test awal ini, diperoleh rata-rata hasil belajar siswa sebesar 30,86, jika dikonversi dengan table distribusi frekuensi maka berada pada kategori sangat rendah. Sedangkan presentase hasil belajar yang diperoleh adalah sebesar $50 \%$ berada dikategori sangat rendah, $50 \%$ berada di kategori rendah, dan $0 \%$ berada di kategori sedang, tinggi, serta sangat tinggi. Jadi, hasil belajar siswa kelas VIIIA SMP Negeri 1 Tinambung Kabupaten Polewali Mandar sebelum diterapkan strategi Mantel Sang Ahli memang sangat rendah.

Tabel 2. Kategori Hasil Belajar Matematika Siswa Kelas VIII SMPN 1 Tinambung Kabupaten Polewali Mandar Sebelum Penerapan Strategi Pembelajaran Mantel Sang Ahli

\begin{tabular}{|c|c|c|c|}
\hline Nilai & Kategori & Frekuensi $(f)$ & Persentase (\%) \\
\hline $0-34$ & Sangat rendah & 12 & 50 \\
$35-54$ & Rendah & 12 & 50 \\
$55-64$ & Sedang & 0 & 0 \\
$65-84$ & Tinggi & 0 & 0 \\
$85-100$ & Sangat tinggi & 0 & 0 \\
\hline Jumlah & & 24 & 100 \\
\hline
\end{tabular}

Strategi Mantel Sang Ahli ini telah menjadikan siswa sebagai subjek belajar artinya siswa yang aktif. Sebagai Sang Ahli, siswa dilatih untuk berani dan terampil dalam berbicara, karena bukan materi saja yang dipelajari tetapi juga tuntutan untuk mengembangkan potensi dirinya secara optimal. Melalui Strategi Mantel Sang Ahli, siswa diberi kesempatan untuk belajar mencari jawaban dengan wawasan dan pengetahuan yang lebih luas, sehingga pada akhirnya apa yang dipelajarinya lebih bermakna bagi dirinya dan bisa berbagi ke teman-temanya.

Pada siklus I, diperoleh hasil belajar dengan nilai rata-rata sebesar 60,58 dan dominan nilai yang diperoleh sudah berada pada kategori sedang sebesar $45,83 \%$ dengan jumlah frekuensi siswa sebanyak 11 orang dari 24 siswa, dan yang berada pada kategori tinggi hanya 10 orang dari jumlah seluruh siswa yaitu 24 orang atau sebesar $41,67 \%$, artinya tidak ada satu pun siswa yang berhasil mencapai kategori sangat tinggi. Sedangkan presentase dari kriteria ketuntasan hasil belajar siswa diperoleh $41,67 \%$ dengan total frekuensi sebanyak 10 orang dari jumlah siswa yang dikategorikan tuntas dan 58,33\% dengan total frekuensi sebanyak 14 orang dari jumlah siswa dikategorikan belum tuntas. Dari hasil siklus I ini, dapat dinyatakan bahwa ketuntasan belajar siswa secara klasikal belum tercapai yang dapat di lihat pada table di bawah ini: 
JURNAL SAINTIFIK VOL.2 NO.1, JANUARI 2016

Tabel 3. Distribusi Frekuensi dan Persentase Skor Hasil Belajar Siswa Kelas VIIIA SMP Negeri 1 Tinambung Kabupaten Polewali Mandar pada Tes Siklus I

\begin{tabular}{|c|c|c|c|}
\hline Nilai & Kategori & Frekuensi $(f)$ & Persentase (\%) \\
\hline $0-34$ & Sangat rendah & 2 & 8,33 \\
$35-54$ & Rendah & 1 & 4,17 \\
$55-64$ & Sedang & 11 & 45,83 \\
$65-84$ & Tinggi & 10 & 41,67 \\
$85-100$ & Sangat tinggi & 0 & 0 \\
\hline Jumlah & & 24 & 100 \\
\hline
\end{tabular}

Tabel 4. Persentase Ketuntasan Hasil Belajar Matematika SiswaKelas VIIIA SMP Negeri 1 Tinambung Kabupaten Polewali Mandar setelah Penerapan Strategi Pembelajaran Mantel Sang Ahli Siklus I

\begin{tabular}{|c|c|c|c|}
\hline Nilai & Kategori & Frekuensi (fi) & Persentase (\%) \\
\hline \multirow{2}{*}{\begin{tabular}{c|c|}
$0-64$ \\
$65-100$
\end{tabular}} & Tidak tuntas & 14 & 58,33 \\
& Tuntas & 10 & 41,67 \\
\hline \multicolumn{2}{|c|}{ Jumlah } & 24 & 100 \\
\hline
\end{tabular}

Rendahnya hasil belajar matematika siswa pada siklus I yang berada pada kategori sedang dan belum mencapai standar ketuntasan belajar secara klasikal karena siswa belum siap untuk menerima pelajaran dengan strategi ini.Siswa belum sepenuhnya tertarik dengan strategi Mantel Sang Ahli. Oleh karena itu berdasarkan refleksi yang dilakukan pada akhir pembelajaran siklus I maka penelitian berlanjut pada siklus II dengan melakukan perbaikan-perbaikan secara optimal.

Pada siklus II, diperoleh hasil belajar dengan nilai rata-rata sebesar 76,16 dan dominan nilai yang diperoleh sudah berada pada kategori tinggi sebesar 58,33\% dengan total frekuensi siswa sebanyak 14 orang dari 24 siswa, dan yang berada pada kategori sangat tinggi sebesar $29,17 \%$ dengan total frekuensi sebanyak 7 orang dari jumlah seluruh siswa. Sedangkan presentase dari kriteria ketuntasan minimal yang diperoleh dikategorikan tuntas sebanyak 21 orang dari 24 siswa atau sebesar 87,50 \% dan hanya 3 orang siswa atau 12,50\% yang dikategorikan tidak tuntas. Dari hasil ini dapat dinyatakan bahwa ketuntasan belajar siswa kelas VIIIA SMP Negeri 1 Tinambung Kab.Polewali Mandar secara klasikal telah tercapai. Berikut adalah table dari hasil penelitian pada siklus II:

Tabel 5. Distribusi Frekuensi dan Persentase Skor Hasil Belajar Siswa Kelas VIIIA SMP Negeri 1 Tinambung Kabupaten Polewali Mandar pada Tes Siklus II.

\begin{tabular}{|c|c|c|c|}
\hline Nilai & Kategori & Frekuensi $(f)$ & Persentase (\%) \\
\hline $0-34$ & Sangat rendah & 2 & 8,33 \\
$35-54$ & Rendah & 0 & 0 \\
$55-64$ & Sedang & 1 & 4,17 \\
$65-84$ & Tinggi & 14 & 58,33 \\
$85-100$ & Sangat tinggi & 7 & 29,17 \\
\hline Jumlah & & 24 & 100 \\
\hline
\end{tabular}


JURNAL SAINTIFIK VOL.2 NO.1, JANUARI 2016

Tabel 6. Persentase Ketuntasan Hasil Belajar Matematika SiswaKelas VIIIA SMPNegeri 1 Tinambung Kabupaten Polewali Mandar Setelah Penerapan Strategi Pembelajaran Mantel Sang Ahli Siklus II

\begin{tabular}{|c|c|c|c|}
\hline Nilai & Kategori & Frekuensi (fi) & Persentase (\%) \\
\hline $0-64$ & Tidak tuntas & 3 & 12,50 \\
$65-100$ & Tuntas & 21 & 87,50 \\
\hline \multicolumn{2}{|c|}{ Jumlah } & 24 & 100 \\
\hline
\end{tabular}

Selain peningkatan pada hasil belajar siswa, juga terjadi peningkatan terhadap sikap dan tingkah laku siswa di kelas yang diamati melalui lembar observasi. Peningkatan tersebut adalah sebagai berikut:

- Terjadi penurunan persentase kehadiran siswa, dari Siklus I sebanyak $100 \%$ selama empat kali pertemuan menjadi 98,62\% pada Siklus II dengan jumlah pertemuan sebanyak 4 kali dan jumlah siswa 24 orang. Jumlah kehadiran siswa yang berkurang sebanyak 1 orang, tidak berpengaruh secara signifikan karena siswa tersebut memang dikategorikan malas.

- Siswa yang memperhatikanpenjelasan materi selama pembelajaran berlangsung pada siklus I $80,54 \%$ meningkat menjadi $90,25 \%$ pada siklus II. Hal ini berarti siswa mulai tertarik dengan strategi yang diterapkan.

- Siswa yang membuat catatan-catatan kecil yang berkaitan dengan materi pada siklus I 83,33 meningkat menjadi 97,20\% pada siklus II. Hal ini berarti siswa mulai terbiasa dan nyaman karena memudahkan siswa untuk mengingat materi.

- Karakteristik siswa bermacam-macam, tiap kelas pasti ada siswa yang melakukan kegiatan lain selama proses belajar mengajar. Siswa yang melakukan kegiatan lain tersebut pada siklus I sebesar 19,41\% menurun menjadi 9,7\%. Artinya ada peningkatan dari siswa yang fokus terhadap penjelasan materi.

- Siswa yang tampil ke depan sebagai Sang Ahli berdasarkan materi yang telah ditentukan pada siklus I sebesar 9,7\% dan pada siklus II tetap 9,7\%. Jika dilihat presentase siswa yang menjadi Sang Ahli berarti tidak ada peningkatan, tapi yang dinilai adalah adanya wajah wajah baru yang tampil sebagai Sang Ahli.

- Siswa yang aktif bertanya dan menanggapi pertanyaan pada siklus I sebesar $11,08 \%$ meningkat menjadi $19,46 \%$. Artinya rasa ingin tahu siswa terhadap materi yang diajarkan mengalami peningkatan.

Dengan melihat hasil tes siswa dan lembar observasi aktifitas siswa, maka secara umum dapat disimpulkan bahwa terjadi peningkatan hasil belajar matematika setelah penerapan strategi pembelajaran Mantel Sang Ahli pada siswa kelas VIIIA SMPN 1 Tinambung Kabupaten Polewali Mandar.

\section{KESIMPULAN}

Berdasarkan hasil penelitian dan pembahasan sebelumnya maka dapat ditarik kesimpulan bahwa ternyata penerapan strategi pembelajaran Mantel Sang Ahli dapat merubah pola belajar siswa dan siswa dapat menunjukkan kemampuan yang dimilikinya untuk selalu aktif dalam proses pembelajaran. Nilai rata-rata hasil belajar pada test kemampuan awal adalah 30,86 menjadi 60,58 dan 76,16 setelah diterapkan strategi Mantel Sang Ahli pada siklus I dan siklus II. Melihat skor yang diperoleh siswa dari siklus I sampai dengan siklus II, maka dapat disimpulkan bahwa penerapan Strategi Pembelajaran Mantel Sang Ahli dapat meningkatkan hasil belajar matematika siswa Kelas VIIIA SMP Negeri 1 Tinambung Kabupaten Polewali Mandar. 
DAFTAR PUSTAKA

Arikunto, Suharsimi, 2009, Penelitian Tindakan Kelas, Bumi Aksara, Jakarta.

Brian, Edmiston, 2010, The 'Mantel dari Pakar' Pendekatan Pendidikan, http:www.mantleoftheexpert.com, diakses tgl 28 September 2010.

Depdikbud, 1994, Kurikulum Pendidikan Dasar GBPP Matematika SLTP, Jakarta.

Ginnis, Paul, 2008, Trik dan Taktik Mengajar, PT Indeks Jakarta.

Kunandar, 2010, Langkah-langkah Mudah Penelitian Tindakan Kelas, PT Raja Grafindo Persada, Jakarta.

Sagal, Syaiful, 2010, Konsep dan Makna Pembelajaran, Alfabeta, Bandung.

Sudijono, Anas, Pengantar Statistik Pendidikan. Jakarta: Raja Grafindo Persada, 2004.

Tiro, M. Arif, 2000, Dasar - Dasar Statistik, State University of Makassar Press, Makassar.

Trianto, 2008, Mendesain Pembelajaran Kontekstual, Cerdas Pustaka Publisher, Jakarta.

Wikipedia, Dorothy Heathcote, http://en.wikipedia.org/wiki/Dorothy Heathcote, diakses tgl 28 September 2010. 